\title{
ANALISIS NILAI-NILAI KECAKAPAN ABAD 21 DALAM BUKU SISWA SD/MI KELAS V SUB TEMA 1 MANUSIA DAN LINGKUNGAN
}

\author{
Arif Widodo $^{1 *}$, Dyah Indraswati ${ }^{2}$, Muhammad Sobri $^{3}$ \\ Universitas Mataram, Prodi Pendidikan Guru Sekolah DasarUniversitas Mataram \\ *Email: arifwidodo@unram.ac.id \\ Corresponding Author \\ dyahindraswati@unram.ac.id \\ Website: https://jurnal.uin-antasari.ac.id/index.php/itjik/index \\ Received: 31 Agustus 2019; Accepted: 17 Desember 2019; Published: 23 Desember 2019
}

\begin{abstract}
This study aims to describe the $21^{\text {st }}$ century skills values contained in the fifth grade student's book sub theme 1 (Human and Environment). The method used is content analysis with data reduction stages, data exposure, and drawing conclusions. Data source in this study is buku lingkungan sahabat kita, the 2013 thematic integrated curriculum book for $\mathrm{SD} / \mathrm{MI}$ grade $\mathrm{V}$. The results of this study indicate that $21^{\mathrm{st}}$ century skills have been developed in learning activities, let's discuss, let's write, let's observe, let's try, let's practice, let's sing, let's sing, let's contemplate, and activities with parents.
\end{abstract}

Key Word: $21^{\text {st }}$ century skills; student books; elementary class V

\begin{abstract}
ABSTRAK
Penelitian ini bertujuan untuk mendeskripsikan nilai-nilai kecakapan abad 21 yang terkandung dalam buku siswa kelas V sub tema 1 (Manusia dan Lingkungan). Metode yang dipakai adalah analisis konten dengan tahapan reduksi data, paparan data, dan penarikan kesimpulan. Sumber data dalam penelitian ini adalah buku lingkungan sahabat kita, buku tematik terpadu kurikulum 2013 untuk SD/MI kelas V tema 8. Hasil penelitian ini menunjukkan bahwa kecakapan abad 21 telah dikembangkan dalam kegiatan pembelajaran ayo berdiskusi, ayo membaca, ayo menulis, ayo mengamati, ayo mencoba, ayo berlatih, ayo bernyanyi, ayo renungkan, dan kegiatan bersama orang tua.
\end{abstract}

Kata kunci: Kecakapan Abad 21; Buku Siswa; SD/MI Kelas V

\section{PENDAHULUAN}

Abad 21 yang dikenal dengan abad teknologi informasi, atau era revolusi industri 4.0 ditandai dengan adanya perkembangan teknologi informasi yang sangat cepat(Redhana, 2019). Perubahan tersebut akan terus berjalan dan sulit diprediksi apa yang akan terjadi, segalasesuatu yang awalnya tidak pernah ada dan tidak terpikirkan sebelumnya bisa saja terjadi pada masa yang akan datang.
Kondisi tersebut telah melahirkan sejumlah tantangan sekaligus peluang(Komara, 2018). Bagi Indonesia yang akan dan sedang berhadapan dengan generasi milenial atau generasi emas, maka memerlukan persiapan yang matang, sebab terkait langsung dengan peningkatan kemajuan bangsa.

Pendidikan mempunyai tanggung jawab yang besar dalam mempersiapkan anak didik agar dapat menjawab tantangan kehidupan, terlebih lagi dalam 
menghadapi kehidupan masa depan yang semakin berat. Pendidikan dikatakan sebagai upaya memanusiakan manusia harus mampu membantu peserta didik dalam mengaktualisasikan semua potensi yang ada menjadi kemampuan agar dapat dimanfaatkan dalam kehidupan sehari-hari di masyarakat. Fungsi pendidikan meliputi pemahaman sosial, kecakapan sosial, sikap sosial, rasa kemanusiaan, kebersamaan, persaudaraan, dan saling tolong-menolong (Haderani, 2018).

$$
\text { Pergeseran paradigma }
$$

pembangunan abad 21 yang berbasis teknologi informasi, komunikasi dan komputerisasi mengharuskan dunia pendidikan untuk berbenah, merancang dan menghasilkan generasi yang mampu beradaptasi sesuai zamannya. Oleh karena itu, Desstya (2015) menegaskan bahwa guru sebagai pusat informasi dan seolaholah sebagai sumber belajar harus diubah, siwa diarahkan untuk mencari tahu informasi secara mandiri dari berbagai sumber belajar, sehingga siswa mampu merumuskan masalah, dan berpikir analisis.

Penanaman dan pengembangan nilai-nilai keterampilan abad 21 kepada anak lebih tepat apabila dilakukan sejak dini terutama pada jenjang sekolah dasar. Pendidikan tingkat dasar merupakan akar pendidikan selanjutnya, proses pembelajaran pada pendidikan dasar akan sangat menentukan keberhasilan siswa pada jenjang sekolah yang lebih tinggi(Rahayuningtyas \& Mustadi, 2018). Hal ini menunjukkan bahwa pendidikan pada jenjang sekolah dasar merupakan pondasi yang penting untuk menanamkan nilai-nilai keterampilan abad 21 sejak dini kepada siswa yang nantinya akan berguna bagi siswa untuk melanjutkan ke jenjang sekolah yang lebih tinggi terlebih lagi dalam menghadapi tantangan abad 21 atau era revolusi industri 4.0 .

Terdapat tiga komponen utama yang paling mendasar dalam proyeksi pendidikan abad 21. Menurut Martini (2018) ketiga komponen utama tersebut dapat dikatakan sebagai kecakapan abad 21. Tiga komponen tersebut yang Pertama, Karakter, Menurut Lickona(tahun)karakter berkaitan dengan konsep moral, sikap moral, dan perilaku moral, sedangkan menurut $\mathrm{Ki}$ Hadjar Dewantara pendidikan karakter mencakup seluruh unsur karakter yang terdiri dari ngerti (olah pikir atau literasi), ngroso (olah hati atau etika )dan nglakoni (olah raga atau kinestika)(Akbar, 2015). Unsur karakter yang perlu menjadi prioritas untuk dikembangkan menurut Kementrian pendidikan dan Kebudayaan (2017) melalui gerakan PPK diantaranya adalah religius, nasionalis, mandiri, gotongroyong, danintegritas(Komara, 2018). Kedua, Kompetensi. Kompetensi yang dibutuhkan siswa dalam menghadapi tantangan abad 21 seperti yang dikemukakan oleh National Education Association (n.d.) dalam(Redhana, 2019)terdiri dari 4C, yang meliputi kemampuan berpikir kritis, kreatif dan inovatif, komunikatif, dan kolaborasi. Menurut (Rachmah, 2014) keterampilan abad ke-21 merupakan kompetensi yang akan membantu peserta didik agar mampu memiliki daya saing global. Ketiga, Literasi. Seiring berjalannya waktu literasi tidak hanya dimaknai sebagai kemampuan baca tulis semata, tetapi juga memiliki makna dan implikasi yang lebih luas untuk memperoleh informasi dan keterbukaan wawasan (Musfiroh \& Listyorini, 2016). Lebih lanjut Suherli Kusmana (2017) menyatakan bahwa konsep literasi merupakan semua tindakan yang dilakukan dalam mencari, memahami serta menguasai informasi. Kementerian Pendidikan dan Kebudayaansetidaknya menyebutkanada enam literasi dasar yang perlu dijadikan prioritas dalam pendidikan kita, diantaranya adalah literasi baca tulis, literasi numerasi, literasi sains, literasi digital, literasi finansial, serta literasi budaya dan kewargaan (Saryono et al., 2017). 
Ketiga komponen tersebut harus termuat dalam buku ajar yang digunakan siswa. Buku ajar dapat digunakan sebagai alat dalam mencapai tujuan pembelajaran serta membantu siswa dalam menemukan sendiri pengetahuannya (Rahayuningtyas $\&$ Mustadi, 2018). Berdasarkan penjelasan diatas maka penelitian ini bertujuan untuk (1). Mendeskripsikan jumlah konten yang bermuatan nilai-nilai kecakapan abad 21 . (2). Menganalisis kelengkapan komponen abad 21 yang terdapat pada setiap kegiatan pembelajaran.

\section{METODE PENELITIAN}

Pendekatan yang dipakai dalam penelitian ini adalah pendekatan kualitatif dengan jenis penelitian analisis konten. Penelitian ini termasuk penelitian kepustakaan melaui kajian teks, dokumen atau buku untuk memperoleh kesimpulan sesuai dengan konteks penggunaanya (Rahayuningtyas \& Mustadi, 2018). Adapun bagian yang dianalisis adalah nilai-nilai keterampilan abad 21 yang terdapat dalam buku siswa SD/MI kelas V.

Sumber data dalam penelitian ini adalah buku tematik terpadu kurikulum 13 edisi revisi 2017 untuk siswa kelas V yang diterbitkan oleh Kementrian Pendidikan dan Kebudayaan tema 8 "Lingkungan Sahabat Kita"yang terdiri dari tiga sub tema utama yaitu manusia dan lingkungan, perubahan lingkungan, dan usaha pelestarian lingkungan serta di tambah lagi satu sub tema yaitu kegiatan berbasis proyek dan literasi.

Pengumpulan data dilakukan dengan analisis dan pencatatan secara detail terhadap buku siswa kelas V tema 8 "Lingkungan Sahabat Kita" dengan unit analisis sub tema 1 "Manusia dan Lingkungan". Instrumen dalam penelitian ini adalah peneliti sendiri yang disusun dalam rubrik berdasarkan teori-teori kecakapan abad 21. Dalam penelitian kualitatif analisis data dapat dilakukan bersamaan dengan pengumpulan data yaitu dengan melakukan pengelompokan (kategorisasi data).Analisis data dapat juga dilakukan dengan cara mendiskusikannya dengan teman sejawat, karena diskusi dengan teman sejawat akan membuat hasil analisis lebih akurat, sehingga kesimpulan yang didapatkannya benar-benar objektif.

Prosedur penelitian analisis konten dilakukan dengan enam langkah yaitu unitzing, sampling, recording, reducing, inferring, dan narrating (Krippendorf, 2013:84) dalam Rahayuningtyas \& Mustadi (2018). Setelah mulai menulis laporan cara yang efektif untuk mengkoreksi kesalahan penulisan dan sebagainya adalah dengan cara mengkomunikasikan dengan teman sejawat, kita dapat saling bertukar tulisan untuk dikoreksi secara bersama-sama.

\section{HASIL DAN PEMBAHASAN}

Buku siswa SD/MI kelas V tema 8 lingkungan sahabat kita terdiri dari 3 sub tema yaitu manusia dan lingkungan, perubahan lingkungan dan usaha perubahan lingkungan. Ketiga sub tema tersebut diuraikan dalam enam pembelajaran yang diharapkan selesai dalam tiga minggu. Pembelajaran bertujuan untuk mengasah daya nalar dan kemampuan berfikir tingkat tinggi, sedangkan minggu keempat diisi dengan kegiatan proyek dan literasi. Kegiatan proyek dan literasi selain untuk melatih kemampuan tingkattinggi juga untuk meningkatkan kemampuan membaca rasa gemar membaca siswa.Pada masingmasing sub tema dikembangkan lagi menjadi beberapa sub judul diantaranya adalah ayo berdiskusi, ayo membaca, ayo menulis, ayo menga-mati, ayo mencoba, ayo berlatih, ayo bernyanyi, ayo renungkan, dan kegiatan bersama orang tua. Tema yang dianalisis dalam buku tersebut adalah sub tema 1 "Manusia dan Lingkungan" yang terdiri dari 6 kegiatan pembelajaran.

Hasil rekapitulasi muatan nilainilai kecakapan abad 21 pada masing- 
masing pembe-lajaran disajikan dalam tabel berikut:
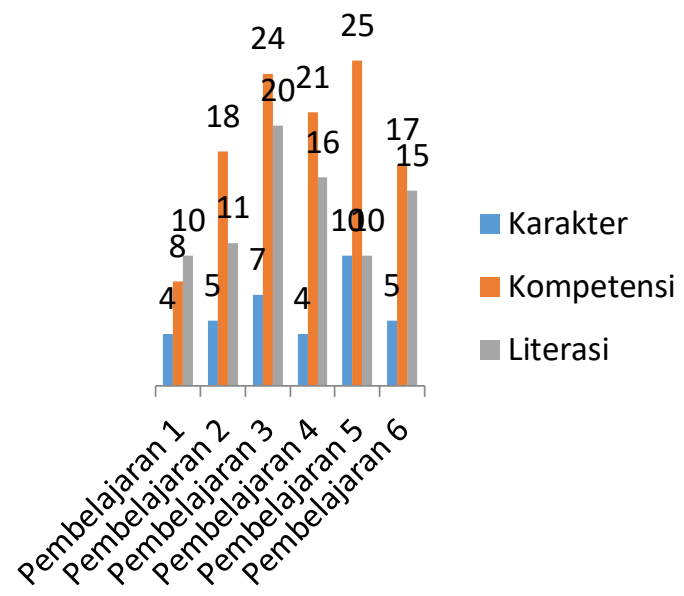

Gambar 1. Jumlah konten yang bermuatan nilai-nilai kecakapan abad 21 pada masing-masing pembelajaran

Nilai-nilai karakter yang dikembangkan pada sub tema "manusia dan lingkungan" pembelajaran 1 diantaranya adalah pantang menyerah yang termuat dalam kegiatan "ayo membaca, kerja sama" yang termuat dalam kegiatan "ayo berdiskusi, kerja sama dan menghargai pendapat orang lain" yang termuat dalam "kegiatan bersama orang tua".

Pembelajaran 2 nilai-nilai karakter yang dikembangkan diantaranya adalah hemat yang termuat dalam kegiatan "ayo membaca siklus air", kerja sama yang termuat dalam kegiatan ayo mencoba, kerja sama dan pantang menyerah yang termuat dalam kegiatan ayo membaca "semut dan beruang", kerja sama yang termuat dalam kegiatan bersama orang tua.

Pembelajaran 3 nilai-nilai karakter yang dikembangkan adalah kerja sama yang termuat dalam kegiatan ayo berdiskusi, toleransi yang termuat dalam kegiatan ayo membaca "keragaman budaya bangsa di wilayah Indonesia", kerja sama, toleransi dan berani yang termuat dalam kegiatan ayo bermain peran, kreatif yang termuat dalam kegiatan ayo membaca "jenis usaha dengan mengolah sumber daya alam", komunikatif yang termuat dalam kegiatan ayo bercerita, kerja sama yang termuat dalam kegiatan bersama orang tua.

Nilai-nilai karakter yang dikembangkan dalam pembelajaran 4 diantaranya adalah kreatif yang termuat dalam kegiatan ayo mencoba, kerjasama dan menghargai orang lain yang termuat dalam kegiatan ayo berdiskusi, toleransi yang termuat dalam kegiatan ayo menulis “...keragaman sosial di tempat tinggal...”.

Pembelajaran 5 nilai-nilai karakter yang dikembangkan adalah cermat yang termuat dalam kegiatan ayo mengamati, riang gembira yang termuat dalam kehiatan ayo membaca "Tangga nada diatonic mayor", berani yang termuat dalam kegiatan ayo bernyanyi, berani dan kreatif yang termuat dalam kegiatan ayo mencoba, kerja sama yang termuat dalam kegiatan ayo berdiskusi, kreatif yang termuat dalam kegiatan ayo membaca "bunga paling berharga", rajin yang termuat dalam kegiatan ayo menulis, kerja sama yang termuat dalam kegiatan bersama orang tua.

Pembelajaran 6 nilai-nilai karakter yang dikembangkan adalah toleransi yang termuat dalam kegiatan ayo membaca "belajar toleransi dari permainan anak", kerja sama yang termuat dalam kegiatan ayo berdiskusi, religius yang termuat dalam kegiatan ayo bernyanyi" lagu syukur", komunikatif yang termuat dalam kegiatan ayo bercerita, kerja sama yang termuat dalam kegiatan bersama orang tua.

Kompetensi yang dikembangkan dalam sub tema 1 "manusia dan lingkungan" diantaranya adalah keterampilan berpikir kritis, kreatif dan inovatif, komunikatif dan kolaboratif. Pada pembelajaran 1, kompetensi yang dikembangkan dalam kegiatan pembelajaran ayo membaca "demi air bersih, warga waborobo rela berjalan sejauh 15 kilo meter" yaitu berpikir kritis, kompetensi yang dikembangkan dalam 
kegiatan pembelajaran ayo berdiskusi yaitu berpikir kritis, komunikatif dan kolaboratif. Kompetensi yang dikembangkan dalam kegiatan ayo renungkan yaitu berpikir kritis. Kompetetensi yang dikembangkan dalam kegiatan bersama orang tua yaitu berikir kritis, komunikatif dan kolaboratif.

Pembelajaran 2, kompetensi yang dikembangkan dalam kegiatan pembelajaran ayo bernyanyi yaitu kreatif dan inovatif, kompetensi yang dikembangkan dalam kegiatan pembelajaran ayo mengamati yaitu berpikir kritis, kolaboratif dan komunikatif. Kompetensi yang dikembangkan dalam kegiatan pembelajaran ayo membaca, yaitu berpikir kritis.Kompetensi yang dikembangkan dalam kegiatan pembelajaran ayo mencoba yaitu berfikir kritis, kreatif dan inovatif, kolaboratif dan komunikatif. Kompetensi yang dikembangkan dalam kegiatan pembelajaran ayo membaca "Semut dan Beruang" yaitu berpikir kritis, kreatif dan inovatif, dan kolaboratif. Kompetensi yang dikembangkan dalam kegiatan ayo renungkan yaitu berpikir kritis. Kompetensi yang dikembangkan dalam kegiatan bersama orang tua yaitu berpikir kritis, komunikatif dan kolaboratif.

Pembelajaran 3, kompetensi yang dikembangkan dalam kegitan pembelajaran ayo membaca "Rumah betang uluk palin" yaitu berpikir kritis. Kompetensi yang dikembangkan dalam kegiatan pembelajaran ayo berdiskusi yaitu berpikir kritis, komunikatif dan kolaboratif. Kompetensi yang dikembangkan dalam kegiatan pembelajaran ayo membaca "Keragaman budaya bangsa di wilayah Indonesia" yaitu berpikir kritis, kreatif dan inovatif, komunikatif dan kolaboratif. Kompetensi yang dikembangkan dalam kegiatan pembelajaran ayo bermain peran yaitu kreatif dan inovatif, komunikatif dan kolaboratif. Kompetensi yang dikembangkan dalam kegiatan pembelajaran ayo membaca "Jenis usaha dengan mengolah sumber daya alam" yaitu berpikir kritis, kreatif dan inovatif. Kompetensi yang dikembangkan dalam kegiatan pembelajaran ayo mengamati yaitu berpikir kritis, kolobaroratif dan komunikatif. Kompetensi yang dikembangkan dalam kegiatan pembelajaran ayo bercerita yaitu komunikatif dan kolaboratif. Kompetensi yang dikembangkan dalam kegiatan pembelajaran ayo renungkan yaitu berpikir kritis. Kompetensi yang dikembangkan dalam kegiatan bersama orang tu yaitu berpikir kritis, komunikatif dan kolaboratif.

Pembelajaran 4, kompetensi yang dikembangkan dalam kegiatan pembelajaran ayo membaca "Jenis usaha masyarakat Indonesia" yaitu berpikir kritis, kreatif dan inovatif. Kompetensi yang dikembangkan dalam kegiatan pembelajaran ayo mencoba yaitu berpikir kritis, kreatif dan inovatif. Kompetensi yang dikembangkan dalam kegiatan pembelajaran ayo berdiskusi yaitu berpikir kritis, komunikatif dan kolaboratif. Kompetensi yang dikembangkan dalam kegiatan pembelajaran ayo menulis yaitu berikir kritis, kreatif dan inovatif. Kompetensi yang dikembangkan dalam kegiatan pembelajaran ayo renungkan yaitu berpikir kritis. Kompetensi yang dikembangkan dalam kegiatan bersama orang tua yaitu berpikir kritis, komunikatif dan kolaboratif.

Pembelajaran 5, Kompetensi yang dikembangkan dalam kegiatan pembelajaran ayo mengamati yaitu berpikir kritis. Kompetensi yang dikembangkan dalam kegiatan pembelajaran ayo bercerita yaitu berpikir kritis dan komunikatif. Kompetensi yang dikembangkan dalam kegiatan pembelajaran ayo bernyanyi yaitu kreatif dan inovatif. Kompetensi yang dikembangkan dalam kegiatan pembelajaran ayo membaca "Tangga nada diatonik mayor"yaitu berpikir kritis, kreatif dan inovatif. Kompetensi yang dikembangkan dalam kegiatan 
pembelajaran ayo mencoba yaitu kreatif dan inovatif. Kompetensi yang dikembangkan dalam kegiatan pembelajaran ayo berdiskusi yaitu berpikir kritis, kolaboratif dan komunikatif. Kompetensi yang dikembangkan dalam kegiatan pembelajaran ayo membaca "Bunga paling berharga"yaitu berpikir kritis, kreatif dan inovatif. Kompetensi yang dikembangkan dalam kegiatan pembelajaran ayo menulis yaitu berpikir kritis, kreatif dan inovatif. Kompetensi yang dikembangkan dalam kegiatan pembelajaran ayo renungkan yaitu berpikir kritis. Kompetensi yang dikembangkan dalam kegiatan bersama orang tua yaitu berpikir kritis, kreatif dan inovatif, komunikatif dan kolaboratif.

Pembelajaran 6, Kompetensi yang dikembangkan dalam kegiatan pembelajaran ayo membaca "Belajar toleransi dari permainan tradisional anak" yaitu berpikir kritis, komunikatif dan kolaboratif. Kompetensi yang dikembangkan dalam kegiatan pembelajaran ayo berdiskusi yaitu berpikir kritis, komunikatif dan kolaboratif. Kompetensi yang dikembangkan dalam kegiatan pembelajaran ayo mengamati yaitu berpikir kritis. Kompetensi yang dikembangkan dalam kegiatan pembelajaran ayo bercerita yaitu berpikir kritis dan komunikatif. Kompetensi yang dikembangkan dalam kegiatan pembelajaran ayo bernyanyi yaitu kreatif dan inovatif. Kompetensi yang dikembangkan dalam kegiatan pembelajaran ayo membaca "tangga nada diatonik minor" yaitu berpikir kritis. Kompetensi yang dikembangkan dalam kegiatan pembelajaran ayo renungkan yaitu berpikir kritis. Kompetensi yang dikembangkan dalam kegiatan bersama orang tua yaitu berpikir kritis, komunikatif dan kolaboratif.

Literasi yang dikembangkan dalam kegiatan pembelajaran 1 yaitu literasi literasi baca tulis, literasi numerasi, literasi sains, literasi digital, literasi finansial, serta literasi budaya dan kewargaan. Pada pembelajaran 1 literasi yang dikembangkan dalam kegiatan ayo membaca yaitu literasi baca tulis, literasi lingkungan, dan literasi sains. Literasi yang dikembangkan dalam kegiatan ayo berdiskusi yaitu literasi baca tulis, literasi lingkungan dan literasi sains. Literasi yang dikembangkan dalam kegiatan ayo renungkan yaitu literasi baca tulis, dan literasi lingkungan. Literasi yang dikembangkan dalam kegiatan bersama orang tua yaitu literasi baca tulis dan literasi lingkungan.

Pada pembelajaran 2, literasi yang dikembangkan dalam kegiatan ayo bernyanyi yaitu literasi budaya. Literasi yang dikembangkan dalam kegiatan ayo mengamati yaitu literasi baca tulis, literasi lingkungan dan literasi sains. Literasi yang dikembangkan dalam kegiatan ayo membaca yaitu literasi baca tulis, literasi lingkungan dan literasi sains. Literasi yang dikembangkan dalam kegiatan yang ayo mencoba yaitu literasi baca tulis dan literasi lingkungan. Literasi yang dikembangkan dalam kegiatan ayo membaca "semut dan beruang" yaitu literasi baca tulis dan literasi lingkungan.

Pada pembelajaran 3, Literasi yang dikembangkan dalam kegiatan ayo membaca yaitu literasi baca tulis, literasi budaya dan kewargaan. Literasi yang dikembangkan dalam kegiatan ayo berdiskusi yaitu literasi baca tulis, literasi lingkungan, literasi budaya dan kewargaan. Literasi yang dikembangkan dalam kegiatan ayo membaca "keragaman budaya bangsa di wilayah Indonesia" yaitu literasi baca tulis, literasi budaya dan kewargaan. Literasi yang dikembangkan dalam kegiatan ayo bermain peran yaitu literasi baca tulis, literasi lingkungan, literasi budaya dan kewargaan. Literasi yang dikembangkan dalam kegiatan ayo membaca "jenis usaha dengan mengolah sumber daya alam" yaitu literasi baca tulis, literasi lingkungan dan literasi sains. Literasi yang dikembangkan dalam kegiatan ayo mengamati "mengamati 
sumber daya alam" yaitu literasi lingkungan dan literasi finansial.

Pada pembelajaran 4, literasi yang dikembangkan dalam kegiatan ayo membaca "jenis usaha masyarakat Indonesia" yaitu literasi baca tulis, dan literasi finansial. literasi yang dikembangkan dalam kegiatanau ayo berdiskusi yaitu literasi baca tulis dan literasi lingkungan. literasi yang dikembangkan dalam kegiatan ayo menulis yaitu literasi baca tulis, literasi lingkungan, literasi budaya dan kewargaan. literasi yang dikembangkan dalam kegiatan ayo renungkan yaitu literasi baca tulis, dan literasi lingkungan. literasi yang dikembangkan dalam kegiatan bersama orang tua yaitu literasi baca tulis dan literasi lingkungan.

Pada pembelajaran 5, literasi yang dikembangkan dalam kegiatan ayo mengamati yaitu literasi baca tulis, literasi budaya dan kewargaan. Literasi yang dikembangkan dalam kegiatan ayo bercerita yaitu literasi baca tulis dan literasi budaya. Literasi yang dikembangkan dalam kegiatan ayo bernyanyi yaitu literasi budaya. Literasi yang dikembangkan dalam kegiatan ayo membaca "tangga nada diatonis mayor" yaitu literasi baca tulis, dan literasi budaya. Literasi yang dikembangkan dalam kegiatan ayo mencoba yaitu literasi baca tulis dan literasi budaya. Literasi yang dikembangkan dalam kegiatan ayo berdiskusi yaitu literasi baca tulis, literasi lingkungan, dan literasi budaya. Literasi yang dikembangkan dalam kegiatan ayo membaca "bunga paling berharga" yaitu literasi baca tulis dan literasi lingkungan. Literasi yang dikembangkan dalam kegiatan ayo menulis yaitu literasi baca tulis dan literasi lingkungan. Literasi yang dikembangkan dalam kegiatan ayo renungkan yaitu literasi baca tulis dan literasi lingkungan.

Pembelajaran 6, Literasi yang dikembangkan dalam kegiatan ayo membaca "belajar toleransi dari permainan tradisional anak" yaitu literasi baca tulis, literasi lingkungan, literasi budaya dan kewargaan. Literasi yang dikembangkan dalam kegiatan ayo berdiskusi yaitu literasi baca tulis, literasi lingkungan, literasi budaya dan kewargaan. Literasi yang dikembangkan dalam kegiatan ayo mengamati yaitu literasi baca tulis, literasi budaya dan kewargaan. Literasi yang dikembangkan dalam kegiatan ayo bercerita yaitu literasi baca tulis, literasi budaya dan kewargaan. Literasi yang dikembangkan dalam kegiatan ayo bernyanyi yaitu literasi budaya dan kewargaan. Literasi yang dikembangkan dalam kegiatan ayo membaca "tangga diatonik minor" yaitu literasi baca tulis, literasi budaya dan kewargaan. Literasi yang dikembangkan dalam kegiatan ayo renungkan yaitu literasi baca tulis, literasi lingkungan dan literasi budaya dan kewargaan. Literasi yang dikembangkan dalam kegiatan bersama orang tua yaitu literasi budaya.

Berdasarkan gambar dapat diketahui bahwasanya kompetensi abad 21 menduduki peringkat pertama dalam frekuensi kemunculannya. Peringkat ke dua literasi dan peringkat ke tiga nilainilai karakter. Kompetensi abad 21 yang dikembangkan diantaranya adalah kemam-puan berpikir kritis, kreatif dan inovatif, kolaboratif dan komunikatif. Literasi yang dikembangkan dalam buku ini diantaranya adalah literasi baca tulis, literasi numerasi, literasi sains, literasi digital, literasi finansial, serta literasi budaya dan kewarganegaraan. Nilai-nilai karakter yang dikembangkan dalam buku ini diantaranya adalah religius, toleransi, kerja sama, pantang menyerah, berani, kreatif, menghormati orang lain, rajin, gembira, cinta kebudayaan dan lingkungan.

Berdasarkan pemaparan di atas dapat diketahui bahwa pada sub tema 1 manusia dan lingkungan telah memuat nilai-nilai kecakapan abad 21 yang tersebar dalam setiap kegiatan pembelajaran yang terdiri dari muatan 
karakter, komptensi abad 21 dan literasi. Hal ini senada dengan pernyataan (Prastowo, 2015) bahwa buku ajar dalam substansinya minimal harus mengandung tiga unsur utama yaitu pengetahuan, keterampilan dan nilai (sikap).

\section{PENUTUP}

Berdasarkan hasil penelitian dapat ditarik kesimpulan bahwa dalam buku siswa terbitan Kementrian Pendidikan dan Kebudayaan Republik Indonesia tahun 2017 tema 8 "Lingkungan Sahabat Kita" sub tema "manusia dan lingkungan" telah memuat nilai-nilai kecakapan abad 21 yaitu karakter, kompetensi dan literasi, yang tersebar dalam setiap kegiatan pembelajaran. Pada buku tersebut kompetensi abad 21 menduduki peringkat pertama dari segi frekuensi kemunculannya dengan proporsi yang seimbang dalam setiap kegiatan pembelajarannya. Hal ini menunjukkan bahwa buku siswa tersebut memberikan ruang yang besar kepada siswa dalam mengembangkan kompetensi berpikir kritis, kreatif dan inivatif, kolaboratif dan komunikatif. Kompetensi-kompetensi tersebut diharapkan akan membantu siswa dalam menghadapi masa depan.

\section{DAFTAR PUSTAKA}

Akbar, S. dkk. (2015). Pendidikan Karakter: Best Practices. Malang: Universitas Negeri Malang.

Desstya, A. (2015). Keterampilan Proses Sains dan Pembelajaran Ipa Di Sekolah Dasar (Telaah Buku Siswa Kelas Iv Sd Tema 2 Karya Sumini). Profesi Pendidikan Dasar 2015 Universitas Muhammadiyah Surakarta, 2(2), 95-102. Retrieved fromhttp://portalgaruda.fti.unissula. ac.id/?ref=browse \&mod=viewarticle \&article $=450051$.

Haderani. (2018). Tinjauan Filosofis Tentang Fungsi Pendidikan Dalam Hidup Manusia. Jurnal Tarbiyah:
Jurnal Ilmiah Kependidikan, 7(1), 48.Retrieved from https://jurnal.uinantasari.ac.id/index.php/jtjik/article/v iew/2103

Komara, E. (2018). Penguatan Pendidikan Karakter dan Pembelajaran Abad 21. SIPATAHOENAN: South-East Asian Journal for Youth, Sports \& Health Education,4(1), 1726.www.journals.mindamas.com/ind ex.php/sipatahoenan

Kusumawati, Heny. (2017). Lingkungan Sahabat Kita. Jakarta: Kemendikbud

Martini, E. (2018). Membangun Karakter Generasi Muda Melalui Model Pembelajaran Berbasis Kecakapan Abad 21. Jurnal Pancasila Dan Kewarganegaraan, 3(2), 21-27. https://doi.org/10.24269/jpk.v3.n2.20 18.pp21-27

Musfiroh, T., \& Listyorini, B. (2016). Konstruk Kompetensi Literasi Untuk Siswa Sekolah Dasar. Litera, 15(1).https://doi.org/10.21831/ltr.v15 i1.9751.

Prastowo, andi. (2015). Panduan Kreatif Membuat Bahan Ajar Inovatif Menciptakan Metode Pembelajaran yang Menarik dan Menyenangkan. Yogyakarta: Diva Press.

Rachmah, H. (2014). Pengembangan Profesi Pendidikan. Bandung: Alfabeta.

Rahayuningtyas, D. I., \& Mustadi, A. (2018). Analisis Muatan Nilai Karakter Pada Buku Ajar Kurikulum 2013 Pegangan Guru Dan Siswa Sekolah Dasar. Jurnal Pendidikan Karakter, Tahun VIII(2), 123-139. https://doi.org/https://doi.org/10.2183 1/jpk.v8i2.21848

Redhana, I. W. (2019). Mengembangkan 
Jurnal Tarbiyah: Jurnal Ilmiah Kependidikan

Vol. 8 No. 2 Juli - Desember 2019 (125-133)

Keterampilan Abad Ke-21 Dalam

Pembelajaran Kimia. Jurnal Inovasi

Pendidikan Kimia,13(1), 2239-2253.

Retrieved

from

https://journal.unnes.ac.id/nju/index.

$\mathrm{php} / \mathrm{JIPK} /$ article/download/17824/89

$\underline{34}$.

Saryono, D., Ibrahim, G. A. I., Muliastuti, L., Akbari, Q. S. A., Hanifah, N., Miftahussururi;, ... Efgeni. (2017).
Materi pendukung literasi baca-tulis. Gerakan Literasi Nasional.

Suherli Kusmana. (2017). PengembanganLiterasi Dalam Kurikulum Pendidikan Dasar Dan Menengah. Diglosia - Jurnal Pendidikan, Kebahasaan, dan Kesusastraan Indonesia, 1(1), 140150. 